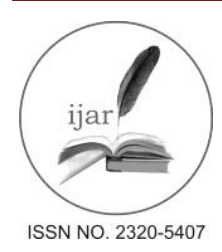

\section{Journal homepage:http://www.journalijar.com Journal DOI: 10.21474/IJAR01}

\section{RESEARCH ARTICLE}

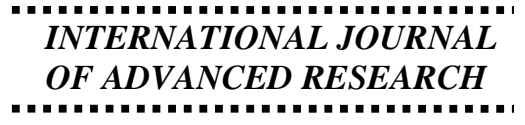

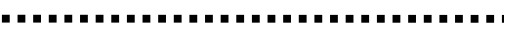

\title{
Diet of Silver Cyprinid, Rastrineobola argentea in Lake Victoria, Kenya.
}

\section{E. Yongo $^{1 *}$, J.O. Manyala ${ }^{1}$, K. Kito ${ }^{2}$, Y. Matsushita ${ }^{2}$, N.O. Outa ${ }^{3}$ and J.M. Njiru ${ }^{4}$.}

1. University of Eldoret, Department of Fisheries and Aquatic Sciences, PO Box 1125-30100, Eldoret, Kenya.

2. Nagasaki University, Graduate School of Fisheries and Environmental Sciences, 1-14 Bunkyo-machi, Nagasaki-shi, Nagasaki 852-8521, Japan.

3. LAVICORD PROJECT, P.O. Box 3105, Kisumu, Kenya.

4. Kisii University, Department of Applied \& Fishery Sciences, P.O Box 408-40200, Kisii, Kenya.

\section{Manuscript Info ABSTRACT}

\section{Manuscript History:}

Received: 14 February 2016

Final Accepted: 29 March 2016

Published Online: April 2016

Key words:

feeding habit, environmental

changes, zooplankton.

*Corresponding Author

Edwine Yongo
Studies on the diet of Rastrineobola argentea were conducted between August 2014 and March 2015 in the Kenyan waters of Lake Victoria. Stomach contents of 1154 specimens collected from commercial fishers and experimental seining were analyzed. Juveniles of $R$. argentea under $30 \mathrm{~mm}$ SL fed almost exclusively on zooplanktons, while adult fish larger than 40 $\mathrm{mm}$ SL preferred insects. Changes in diet require morphological and physiological changes which are not yet well developed in young fish, thus, they can easily digest zooplankton that also satisfy their demand for protein.Diel feeding regime suggested that $R$. argentea is a visual feeder. There was spatial variation in diet composition within the studiedstations. Strauss Linear Index of food selection showed that $R$. argentea preferred cyclopoida, Daphnia sp and Brachionus sp(positive values). However, calanoida, Bosmina sp and Keratella sp were avoided in most stations (negative values). The change in diet among the stations could be attributed to the environmental changes occurring in Lake Victoria associated with changes in composition and abundance of zooplankton community. The information on the ecology of $R$. argentea are of considerable ecological importance.

Copy Right, IJAR, 2016. All rights reserved

\section{INTRODUCTION:-}

The Silver Cyprinid, Rastrineobola argentea (Pellegrin, 1904), is a species of ray-finned fish in the family Cyprinidae of order Cypriniformesfrom Lakes Victoria and Kyoga in East Africa.Its diet predominantly consists of zooplanktons, mainly copepods,cladocerans and rotifers(Wandera, 1992;Wanink, 1998). The diel behaviour of $R$. argentea is associated with feeding on insects near the surface at night and aggregating in the lower water column around the oxycline during the day and feeding on zooplankton (Getabu et al., 2003). According to Mkumbo (2002), R. argenteais one of the main prey items of the introduced Nile perch (Lates niloticus), that provides income, foreign exchange and employment to the fisher communities and the countries sharing the lake. The fish therefore, has a crucial role in the ecosystem of Lake Victoria as a link between the zooplankton and the top predators (Manyala and Ojuok, 2007). The composition and abundance of zooplankton community in Lake Victoria has changed significantly following the deteriorating water quality caused by increased disturbances in its catchments (Ngupula et al., 2010). This is thought to have an impact on the feeding ecology of $R$. argenteain the lake since zooplankton forms its major food item.In regard tothis effect, the study aimed to determine the diet composition, ontogenic shift, spatial variation in diet composition, diel feeding and food selection of $R$. Argenteain the Kenyan waters of Lake Victoria. 


\section{MATERIALS AND METHODS:-}

\section{Study area:-}

This study was conducted in the Kenyan waters of Lake Victoria (Fig.1), with sampling stations at Dunga

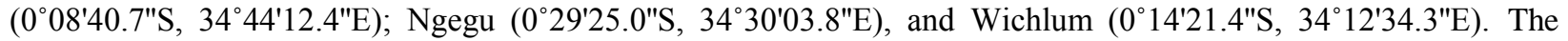
fishery at Dunga is shallow (3-4 m) covering the inner Nyanza gulf waters. Ngegu is deep (8-14 m) and covers the mid Nyanza gulf waters. Wichlum is shallow $(5-7 \mathrm{~m})$ covering the open waters.

\section{Sampling procedures:-}

Studies on the diet of $R$. argentea were conducted between August 2014 and March 2015. Stomach contents of 1154 specimens collected from commercial fishers and experimental seining were analyzed. For diel feeding regime, a 24-h sampling was conducted in every station using small seine net of mesh-size 8mm, length $100 \mathrm{~m}$ and width 8 m. Fishing was done at $3-\mathrm{h}$ interval and fish samples were preserved in $5 \%$ formalin. Parallel to fishing, composite vertical samples of zooplankton were collected from the water column using $50 \mu \mathrm{m}$ plankton net of $30 \mathrm{~cm}$ diameter and preserved in $500 \mathrm{ml}$ vials with $5 \%$ formalin. In the laboratory, the samples were washed with water to remove the formalin, and then diluted to $100 \mathrm{mls}$ of which $10 \mathrm{mls}$ were sub-sampled for counting using an inverted microscope at x 100 magnification. The zooplankton was identified using keys by Jung (2004). The stomach contents (SC) of the preserved fish were weighed $(0.1 \mathrm{mg})$ using an electronic balance (Mettler Toledo, AG204). The contents were then put into a petri dish and the zooplanktons sorted and identified under a microscope. Strauss Linear index (Strauss, 1979) was used to calculate food selection according to the equation; $\boldsymbol{L}_{i}=\boldsymbol{r}_{\boldsymbol{i}} \boldsymbol{-} \boldsymbol{p}_{\boldsymbol{i}}$, where $\boldsymbol{r}_{\boldsymbol{i}}$ is the proportion of prey taxon $i$ in the guts of predators and $\boldsymbol{p}_{i}$ is the proportion of the same taxon in the environment. The means of $\boldsymbol{r}_{i}$ and $\boldsymbol{p}_{i}$ weighed by the number of prey in each sample was used to calculate $\boldsymbol{L}_{\boldsymbol{i}}$

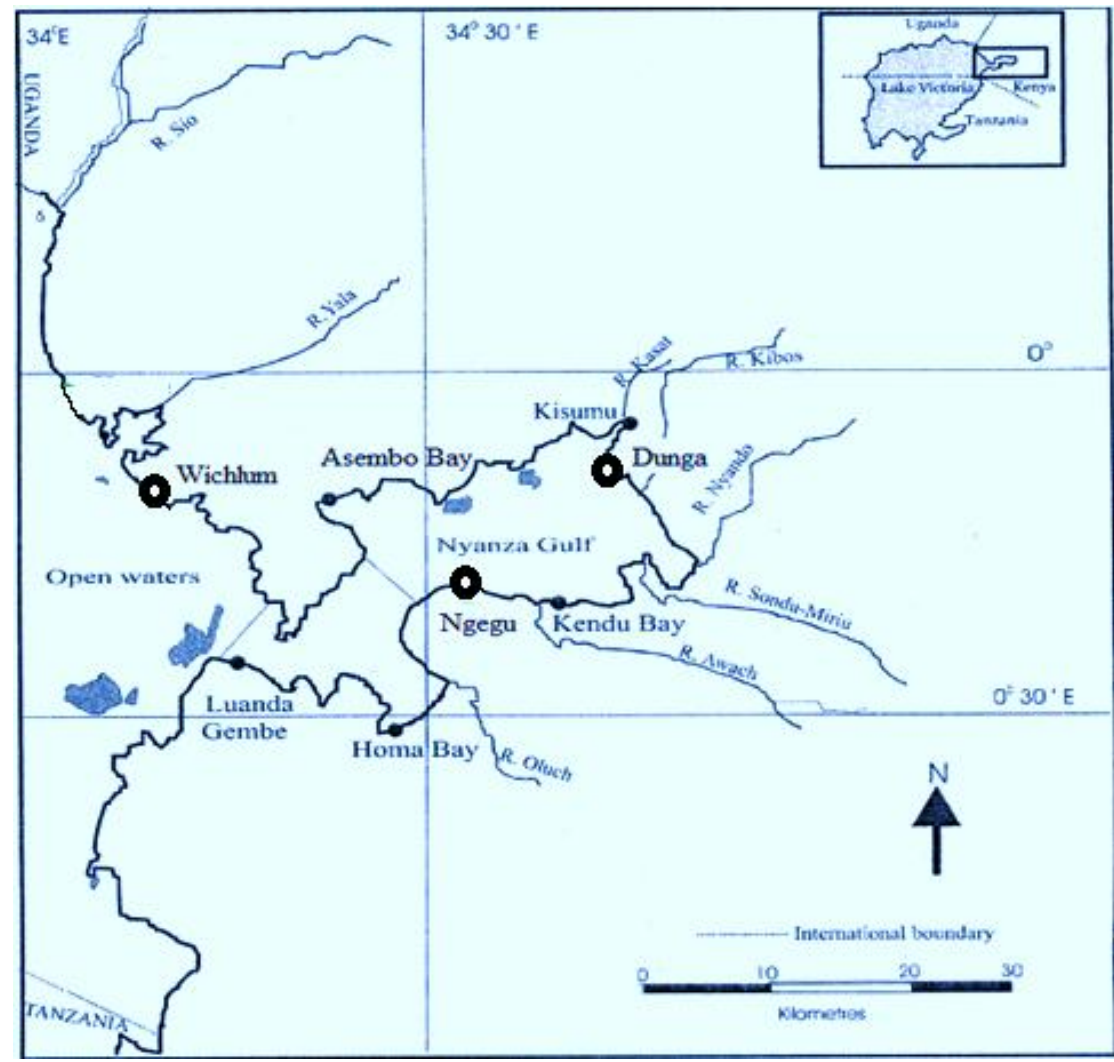

Fig. 1: Map of Lake Victoria, Kenya showing the sampling stations 


\section{RESULTS:-}

\section{Diet composition:-}

During the period of August 2014 to March 2015 the gut contents of 1154 specimens of $R$. argentea consisted mostly of copepods, cladocerans, rotifers and insects (Fig. 2). Copepods contributed the highest (34.6\%) while insects contributed the least (18.7\%).

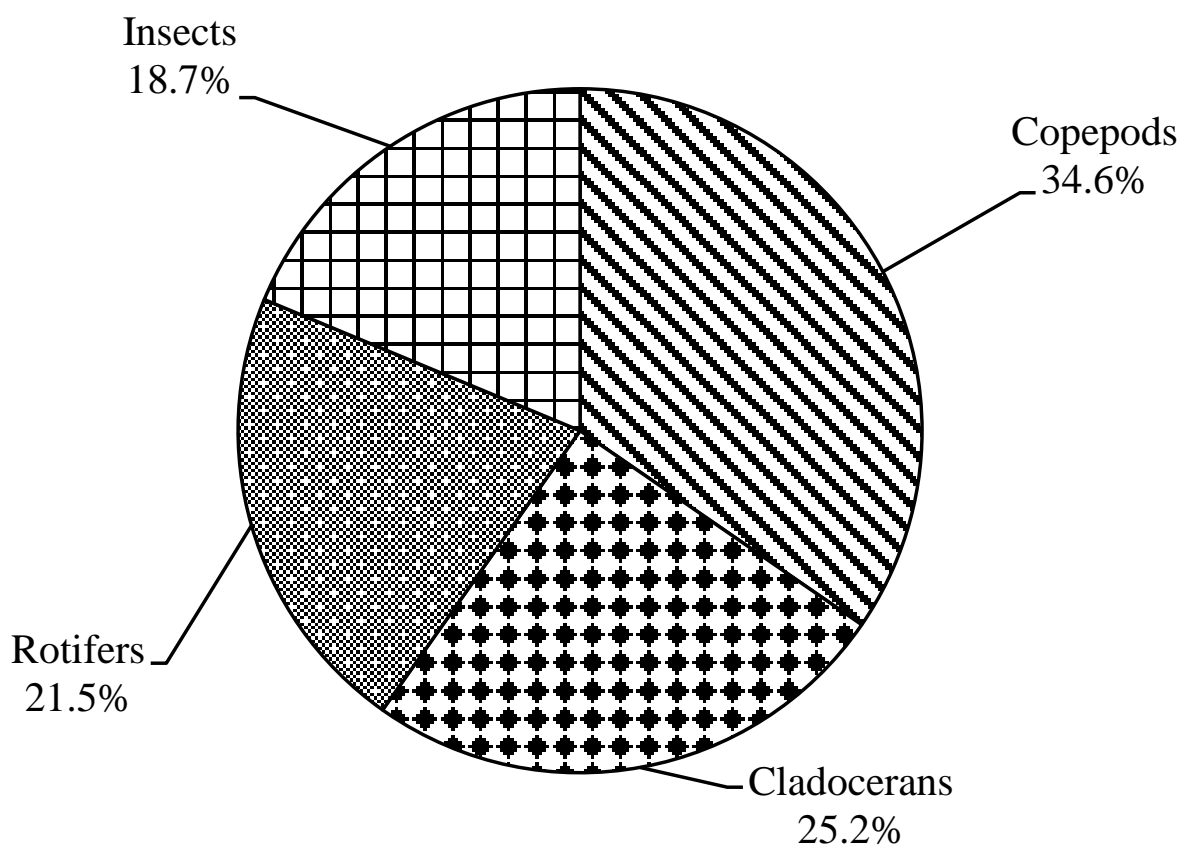

Fig. 2: Contribution of different food items in the diet of R. argentea in Lake Victoria.

\section{Spatial variation in diet composition:-}

There was spatial variation in the composition of the food items consumed by $R$. argentea from the three sampled stations in Lake Victoria (Table 1). The dominant food items in the diet were rotifers (36.8\%), copepods (54.2\%) and insects (32.0\%) at Dunga, Ngegu and Wichlum. The other important food item in the lake was cladoceran. Chisquare test revealed significant difference between the ingested copepods $\left(\chi^{2}=16.96, p<0.05\right)$, rotifers $\left(\chi^{2}=17.51\right.$, $\mathrm{p}<0.05)$ and insect $\left(\chi^{2}=21.63, \mathrm{p}<0.05\right)$ in the three stations. No significant spatial variation was detected with cladocerans $\left(\chi^{2}=5.72, \mathrm{p}>0.05\right)$.

Table 1: Numbers and percentages (\%)of various food items in the guts of $R$. argentea from various stations in Lake Victoria, Kenya.

\begin{tabular}{llll}
\hline Food items & Dunga & Ngegu & Wichlum \\
\hline Copepods & $38(27.1)$ & $70(54.2)$ & $36(22.5)$ \\
Cladocerans & $22(15.6)$ & $41(31.7)$ & $45(28.3)$ \\
Rotifers & $52(36.8)$ & $14(10.4)$ & $28(17.2)$ \\
Insects & $29(20.5)$ & $5(3.7)$ & $51(32.0)$ \\
\hline
\end{tabular}

\section{Food in relation to fish size}

The fish examined ranged from 27 to $59 \mathrm{~mm}$ SL. A change in the diet with increasing size was apparent, with all size classes consuming all the important food items (Fig. 3). copepods were the major food of R. argentea under 30 $\mathrm{mm} \mathrm{SL}$, and was of little importance to fish larger than $40 \mathrm{~mm}$ SL. Insects were also of little importance in the diet of small $R$. argentea $(<30 \mathrm{~mm})$, but were major food items of larger fish. Cladocerans and rotifers were consistently important to all size groups. 


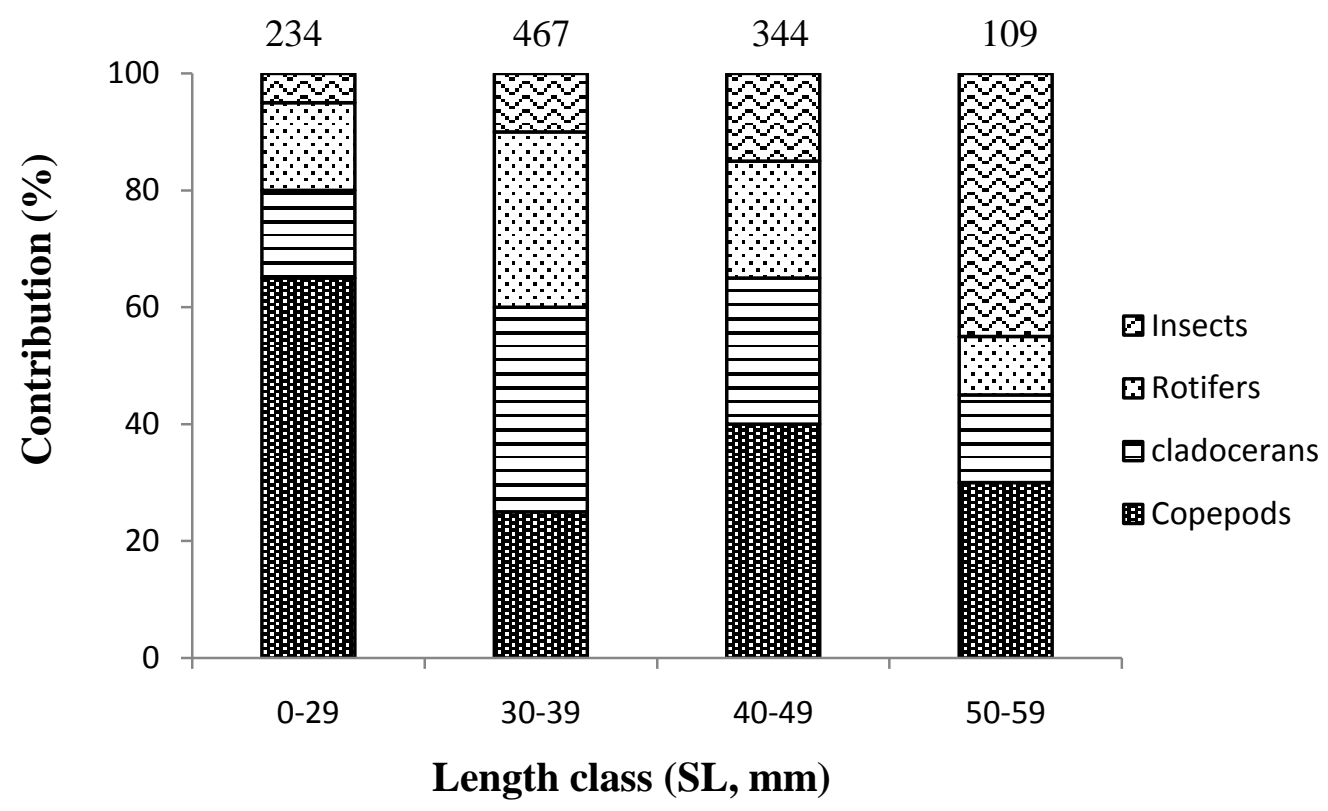

Fig. 3: Food of R.argentea of different length classes from Lake Victoria, Kenya. Numbers above columns indicate sample size (n).

Diel feeding rhythm:-

A 24-h feeding study showed that $R$. argentea fed mostly during the day, and ingests very little food at night. The feeding regime at Ngegu showed two peaks around $6 \mathrm{pm}$ and $6 \mathrm{am}$, whereas at Wichlum the peaks were around $6 \mathrm{pm}$ and 9am (Fig 4). The stomach contents reduces reaching the lowest levels at midnight (Ngegu) and 3am (Wichlum). An increase in the stomach contents was recorded from around 3 am and 6 am at Ngegu and Wichlum respectively.
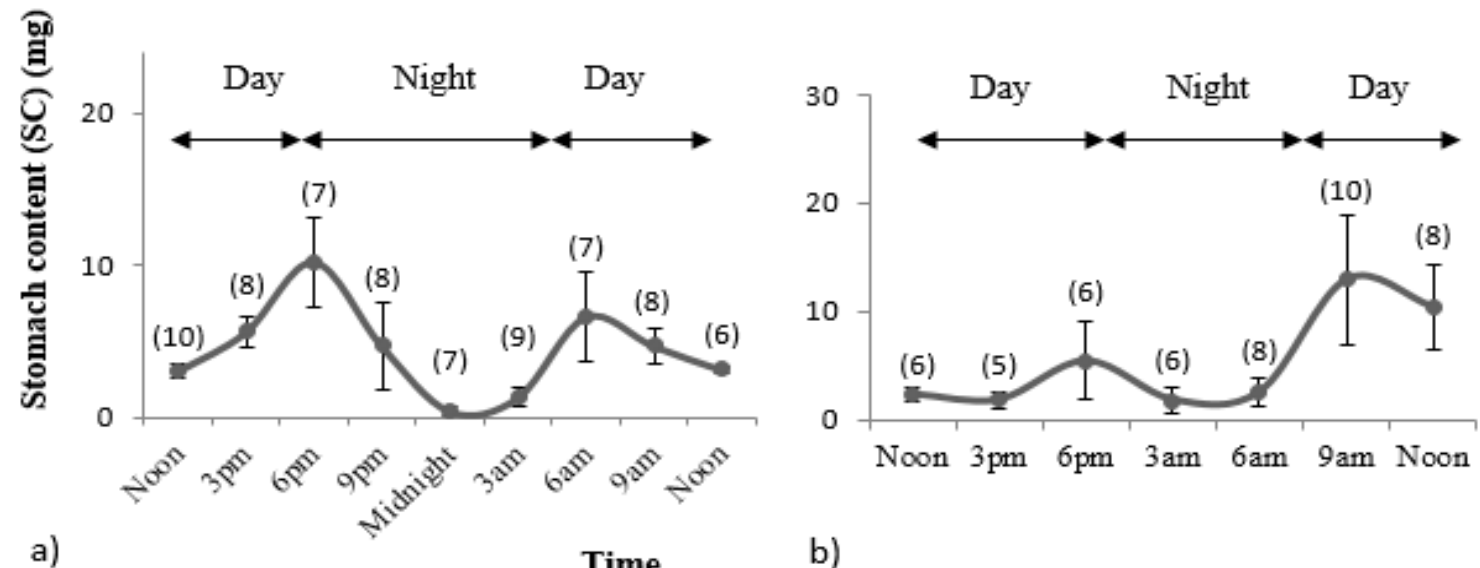

b)

Fig. 4: Diel feeding regime of $R$. argentea in Lake Victoria, Kenya. a) Ngegu, b) Wichlum. Vertical lines indicate the mean \pm SE. Parentheses indicate sample size (n).

\section{Food selection:-}

Strauss Linear Index of food selection showed that $R$. argentea preferred cyclopoida (Ngegu), Daphnia sp (Wichlum) and Brachionus sp (Dunga) (positive values). However, calanoida, Bosmina sp and Keratella sp were avoided in most stations (negative values) (Fig. 5). 


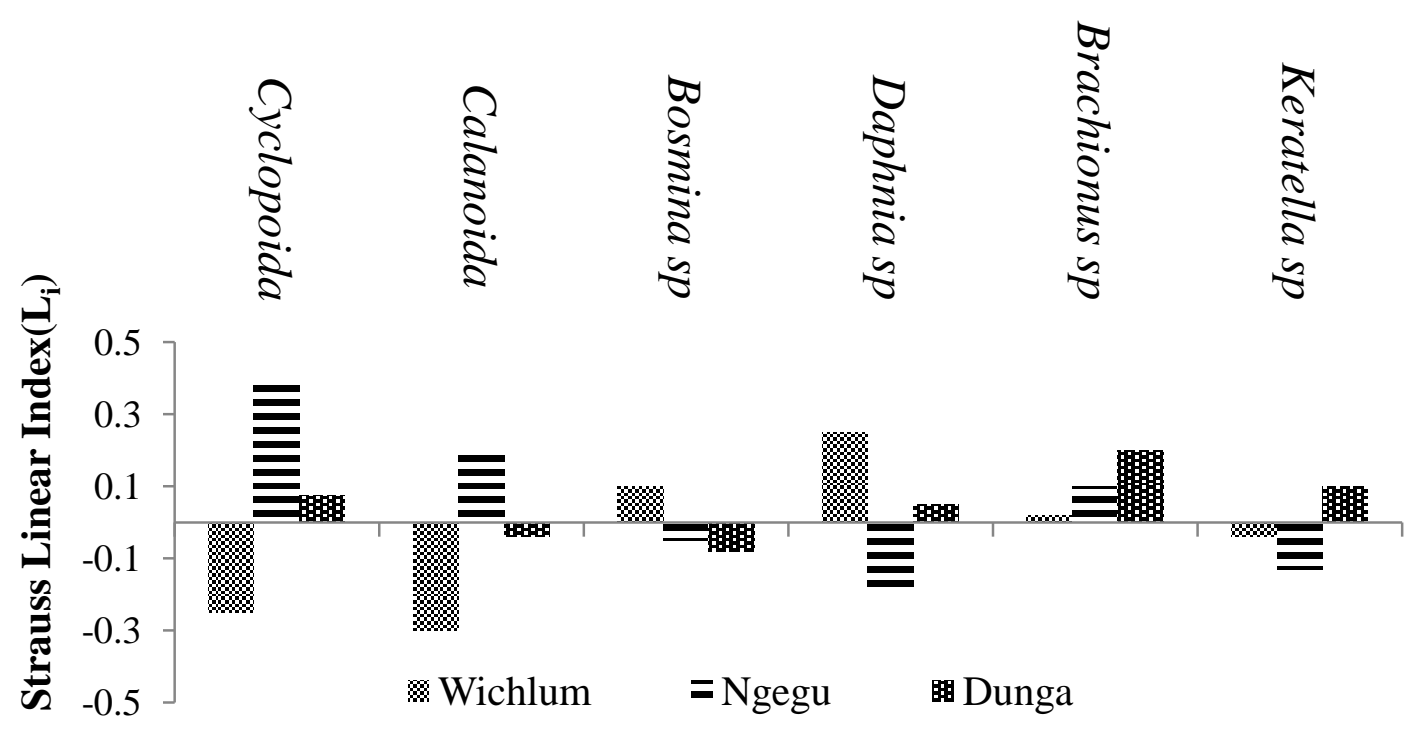

Fig. 5: Selectivity of zooplankton species by $R$. argentea in Lake Victoria, Kenya.

\section{DISCUSSION:-}

The study identified four food items of $R$. argentea, i.e. copepod, cladoceran, rotifers and insects, of which copepod contributed the highest proportion of the diet. This could be attributed to their high abundance in the lake. The law of optimal foraging could also explain that the fish preferred copepods because of the higher net energy gain (Krebs, 1979). These results concur with Wandera (1992) who found copepods forming the major diet of $R$. argentea in the Ugandan waters of Lake Victoria.However, Budeba and Cowx (2007) identified six food items of R. argentea, i.e. C. nilotica, cladoceran, copepod, chaoborus, insects and chironomids in the Tanzanian part of Lake Victoria. Results for the spatial diet composition differ from Owili (1999) who reported the dominance of cladoceran in the diet of $R$. argentea in the Nyanza gulf of Lake Victoria. The change in diet among stations could be attributed to the environmental effectscausing changes in zooplankton community (Ngupula et al., 2010). According to Wanink et al (2002) the zooplanktivore fish (i.e. R. argentea, haplochromines, and juveniles of Nile perch) do not have any significant preferences towards big sized calanoids and cladocerans.Juveniles of $R$. argentea under $30 \mathrm{~mm}$ SL fed almost exclusively on zooplanktons. Njiru et al (2004) made similar observations in the lakereporting zooplankton as the major food of Oreochromis niloticus under $5 \mathrm{~cm}$ TL. The dominance of zooplankton in the diet of juvenile $R$. argentea was probably because of their smaller mouth gape (Wandera, 1992). Changes in diet require morphological and physiological changes which are not yet well developed in young fish, thus, they can easily digest zooplankton that lack cell wall (Govoni et al., 1986). Juvenile fish require more energy for active growth and in such they depend on zooplankton to satisfy their demand for protein (Benavides et al., 1994). Diel feeding regime suggested that $R$. argentea is a visual feeder.The visual responsiveness in fish is decreased at night because the photoreceptors (rod and cone) are actively depolarized in the dark and hyperpolarize in the light (Emran et al., 2010). The low stomach contents recorded at night was mainly due to the completion of digestion of the food consumed during the day, while the rise in stomach contents from dusk could be as a result of feeding by the fish to satisfy the demand after the digestion at night. These results concur with Wandera (1992) who reported the highest and least feeding peaks during day and night respectively, with digestion completed after midnight. Outa et al(2014) also reported almost similar diurnal feeding regimewith $O$. niloticus in Lake Naivasha, Kenya.

\section{Conclusion:-}

R. argentea fed mostly during the day, with preference to copepods among zooplankton groups. The change in diet among the stations could be attributed to the environmental changesoccurring in Lake Victoria associated withchanges in composition and abundance of zooplankton community. The information on the ecology of $R$. argentea are of considerable ecological importance. 


\section{Acknowledgements:-}

This research was funded by Lake Victoria Comprehensive Ecosystem \& Aquatic Environment Research Development (LAVICORD) Project and the Core-to-Core Program by Japan Society for the Promotion of Science (JSPS).We wish to thank the Africa research stationsof Nagasaki University for the good collaboration in undertaking the research

\section{References:-}

Benavides, A.G., Cancino, J.M., \&Ojeda, F.P. (1994). Ontogenetic change in gut dimensions and microalgal digestibility in the marine herbivorous fish, Aplodactylus punctatus.Functional Ecology. 8, 46-51.

Budeba, Y.L., \& Cowx, I.G. (2007). The role of the freshwater shrimp, Caridina nilotica (Roux) in the diet of the major commercial fish species in Lake Victoria, Tanzania. Aquatic Ecosystem Health and Management. 10 (4), 368-380.

Emran, F., Jason, R., Alan, R., Adolph, A.R., \&Dowling, J.E. (2010). Zebrafish larvae lose vision at night. Proc Natl Acad Sci. 107 (13), 6034-6039.

Getabu, A., Tumwebaze, R., \&MacLennan, D.N. (2003). Spatial distribution and temporal changes in the fish populations of Lake Victoria. Aquatic Living Resources Journal.16, 159-165.

Govoni, J.J., Boehlert, G.W., \&Watanabej, Y. (1986). The physiology of digestion in fish larvae. Environmental Biology of Fishes. 16 (1-3), 59-77.

Jung, F. (2004).A Guide to Tropical Freshwater Zooplankton Identification, ecology and impact on fisheries. Aquatic Ecology. 38 (1-432).

Krebs, J.B. (1979). Foraging strategies and their social significance. In Martens, P., Vandenbergh, J.G. (Eds.), Handbook of Behavioural Neurobiology. Plenum Press, New York.

Manyala, J.O., \&Ojuok, J.E. (2007).Survival of the Lake Victoria Rastrineobola argenteain a rapidly changing environment: Biotic and abiotic interactions. Aquatic Ecosystem Health and Management. 10 (4), $407-415$.

Mkumbo, O.C. (2002).Assessment and management of the Nile Perch (Lates niloticus) Stocks in the Tanzania waters of Lake Victoria. PhD Thesis, University of Hull, England.

Ngupula, G.W., Waya, R.K., \&Ezekiel, C.N. (2010) Spatial and temporal patterns in abundance and distribution of zooplankton in the Tanzanian waters of Lake Victoria. Aquatic Ecosystem Health and Management. 13 (4), 451-457.

Njiru, M., Okeyo-Owuor, J. B., Muchiri, M., \&Cowx, I. G. (2004). Shifts in the food of Nile tilapia, Oreochromis niloticus in Lake Victoria, Kenya. African Journal of Ecology. 42, 163-170.

Outa, N.O., Kitaka, N., \&Njiru, J.M. (2014).Some aspects of the feeding ecology of Nile tilapia, Oreochromis niloticus in Lake Naivasha, Kenya. International Journal of Fisheries and Aquatic Studies. 2 (2), 1-8.

Owili, M. (1999).Zooplankton-fish interaction in the littoral zone of Nyanza Gulf, Lake Victoria. In Cowx, I.G., Tweddle, D. (Eds.), Technical Document, pp. 163-174.

Strauss, R.E. (1979).Reliability estimates for Ivlev's Electivity Index, the forage ratio, and a proposed linear index of food selection. Transactions of the American Fisheries Society. 108, 344-352.

Wandera, S.B. (1992).A study of Rastrineobola argentea in the Ugandan lakes. In Mannini, P. (Ed.), The Lake Victoria Dagaa (Rastrineobola argentea), pp. 36-41.

Wanink, J.H. (1998).The pelagic cyprinid Rastrineobola argentea as a crucial link in the disrupted ecosystem of Lake Victoria' Dwarfs and giants-African Adventure, Ponsen and Looijen B.V, Wageningen, The Netherlands.

Wanink, J.H., Katunzi, E.F.B., Goudswaard, K.P.C., Witte, F., \&van Densen, W.L.T. (2002). The shift to smaller zooplankton in Lake Victoria cannot be attributed to the 'sardine' Rastrineobola argentea (Cyprinidae). Aquatic Living Resources. 15, 37-43. 